\title{
A Framework for Operationalizing Climate-Just Ocean Commitments Under the Paris Agreement
}

\author{
Sarah M. Reiter ${ }^{1 *}$, Laura M. Cheng ${ }^{1}$, Angelique Pouponneau ${ }^{2}$, Sophie Taylor ${ }^{3}$ and \\ Lisa M. Wedding ${ }^{3}$
}

${ }^{1}$ Vermont Law School, South Royalton, VT, United States, ${ }^{2}$ Seychelles Conservation and Climate Adaptation Trust, Victoria, Seychelles, ${ }^{3}$ School of Geography and the Environment, University of Oxford, Oxford, United Kingdom

OPEN ACCESS

Edited by:

Ugur Soytas,

Technical University of

Denmark, Denmark

Reviewed by:

Jason MacLean

University of New Brunswick

Fredericton, Canada

Marjan Peeters,

Maastricht University, Netherlands

*Correspondence:

Sarah M. Reiter

sreiter@vermontlaw.edu

Specialty section:

This article was submitted to

Climate Law and Policy,

a section of the journal

Frontiers in Climate

Received: 11 June 2021

Accepted: 14 September 2021

Published: 28 October 2021

Citation:

Reiter SM, Cheng LM, Pouponneau A

Taylor S and Wedding LM (2021) A

Framework for Operationalizing

Climate-Just Ocean Commitments

Under the Paris Agreement.

Front. Clim. 3:724065.

doi: 10.3389/fclim.2021.724065
Building on the considerable momentum from the commencement of the Decade of Ocean Science, the Ocean-climate nexus will be center stage at COP26. Many countries are including blue carbon Ocean commitments in their second round of nationally determined contributions (NDCs), and there is a need to harmonize the science, law, and economics of Ocean-based climate mitigation and adaptation strategies to enable implementation of Ocean commitments under the Paris Agreement. In addition, consistent with the Paris Agreement preamble's focus on human rights, the rights and empowerment of vulnerable and marginalized communities, and intergenerational equity, the design and implementation of Ocean commitments in NDCs should be centered on considerations of climate justice ("climate-just Ocean commitments"). The challenges and opportunities inherent in implementing climate-just Ocean commitments require a comprehensive review of the latest innovations in blue carbon scientific research, the enabling conditions necessary for uptake of this science into policies and decision making, and the financial structures needed to equitably finance Ocean nature-based solutions. Responding to this need, we propose that a framework is needed to support the inclusion of blue carbon sequestration potential in ambitious national and subnational action. The proposed framework should center on the intersectionality of climate justice with the three key layers essential to implementation of Ocean commitments-science, law, and economics - where traditional and local ecological knowledge is valued on par with western science, law and policy centers on vulnerable communities, and financial mechanisms respect national sovereignty, value local cultures, and support sustainable economic development.

Keywords: blue carbon, nature-based solutions, climate justice, climate finance, Paris agreement

\section{INTRODUCTION}

Over the past several years, Parties to the Paris Agreement have called for the formal recognition of the Ocean-climate nexus in climate agreements and negotiations. The Ocean-climate nexus establishes that the Ocean is inextricably linked to the climate: while climate change and other human activities are harming the Ocean, the Ocean plays a key role in regulating climate (Thornton et al., 2009) and Ocean nature-based solutions can significantly contribute to climate change mitigation and adaptation (Seddon et al., 2019).

Under the Paris Agreement, countries are required to submit progressively ambitious Nationally Determined Contributions (NDCs) every 5 years detailing how the country will mitigate and adapt 
to climate change. These should be written with the goal of keeping the increase in global average temperature to well below $2^{\circ} \mathrm{C}$, and ideally below $1.5^{\circ} \mathrm{C}$, above pre-industrial levels, based on the IPCC's 2018 Special Report [Article 2.1 (a) of the Paris Agreement]. Successive NDCs must reflect the "highest possible ambition" to combat climate change (Article 4.3, United Nations, 2015). Appreciating the Ocean-climate nexus, several nations have committed to making their second round of NDCs "Ocean-inclusive" (Gallo et al., 2017). Ocean-inclusive NDCs exist on a spectrum and place a higher emphasis on Oceanrelated nature-based mitigation and adaptation measures. Many nations prioritize Ocean-related climate change mitigation and adaptation measures aimed at achieving a balance between greenhouse gas (GHG) source emissions and sink removals (Lecerf et al., 2021). As Ocean-inclusive NDCs play an increasingly vital role in accomplishing the Paris Agreement's goals, there is a need to establish a framework to operationalize climate-just Ocean commitments.

To succeed, climate-just Ocean commitments which include blue carbon strategies must integrate three primary disciplines: science, law and policy, and finance, while centering on climate justice and human rights. Climate justice extends beyond reflecting common but differentiated responsibilities, primarily through obligations that developed nations fund developing nation commitments (United Nations, 2015). The spirit of the Paris Agreement embraces a focus on climate justice, stating in the Preamble, "Parties should, when taking action to address climate change, respect, promote and consider their respective obligations on human rights, the right to health, the rights of indigenous peoples, local communities, migrants, children, persons with disabilities and people in vulnerable situations and the right to development, as well as gender equality, empowerment of women and intergenerational equity..." (Preamble, United Nations, 2015). The Paris Agreement, although not creating any new human rights obligations, reminds Parties that existing human rights commitments apply to climate change management strategies (Robinson and Shine, 2018). Nevertheless, as Robinson and Shine (2018) highlight, climate action strategies can themselves result in injustices, for example food prices rising as a result of crops being used for biofuels rather than food. Further, climate adaptation and mitigation projects failing to consult local people are often rejected by these communities and rendered unsuccessful (Penz et al., 2011; Hunsberger et al., 2017). To move climate justice from preamble to practice, we call for a framework to operationalize Ocean commitments: one which values local and indigenous cultures, knowledge, and beliefs, and respects the sovereignty and sustainable development rights of developing nations.

\section{FRAMEWORK FOR OPERATIONALIZING CLIMATE-JUST OCEAN COMMITMENTS}

Climate-just Ocean commitments will be born from three layers: (1) a scientific process co-designed with local stakeholders to achieve ecosystem health and integrate traditional ecological knowledge (TEK); (2) a policy process ripe for the uptake of blue carbon strategies, designed to establish co-management structures, and measured against gentrification, displacement, and equitable access to expertise; and (3) public and private financing mechanisms that preserve national sovereignty, incorporate social and ecological values into market valuations, and support sustainable economic development (Figure 1). We outline the foundation necessary to achieve climate-just Ocean commitments under the Paris Agreement by providing a snapshot of the operational inquiries, potential enabling conditions, and preliminary examples leading the way in implementing blue carbon strategies (Table 1). With the global stocktake occurring from 2021-2023, we advocate that Oceanbased climate adaptation, mitigation, and finance flows can contribute to the collective goals of the Paris Agreement while placing people at the core. Article 14 of the Paris Agreement states that the Global Stocktake should "assess collective progress" whilst considering mitigation and adaptation, and "in the light of equity and the best available science" (United Nations Framework Convention on Climate Change, 2018). This paper notes the adaptive and mitigative nature of blue carbon habitats to climate change, whilst focusing on emerging science and equitable legal frameworks. Blue carbon habitats can be quantified and included in the Global Stocktake using methodologies outlined in the 2013 Supplement to the 2006 IPCC Guidelines for National Greenhouse Gas Inventories: Wetlands (IPCC, 2013).

\section{LAYER ONE: COUPLING BLUE CARBON SCIENCE WITH COASTAL TRADITIONAL ECOLOGICAL KNOWLEDGE}

Coastal ecosystems, namely seagrass, mangroves, and wetlands, contribute to both climate mitigation and adaptation measures (Himes-Cornell et al., 2018). "Blue carbon" is carbon sequestered in coastal ecosystems, and could be critical for reaching netzero emissions in the coming years (Mcleod et al., 2011). Nonetheless, future higher global warming scenarios threaten these ecosystems, meaning that the carbon stored within them could be lost if these ecosystems are destroyed (Bindoff et al., 2019). Time is running out for including blue carbon habitats in negative emissions policy as many coastal countries have already lost a significant proportion of these ecosystems; for example, $44 \%$ of UK seagrass has been lost since 1936 (Green et al., 2021). Often overlooked, coastal ecosystems can sequester carbon at rates nearly two orders of magnitude >terrestrial forests per unit area (Mcleod et al., 2011), and are included in NDCs of many small island or high coastal population countries (Gallo et al., 2017). However, if disturbed, these coastal habitats start emitting carbon (Beaumont et al., 2014), and must be protected to maintain their carbon sequestration function (Crooks et al., 2011) and other key ecosystem services.

Mapping and quantifying the location and abundance of blue carbon habitats and the carbon sequestered by these ecosystems in both biomass and soils is an important initial step to incorporate blue carbon into NDCs. Coastal communities across the world could attempt to claim the right to be involved in environmental science and management projects such as blue 


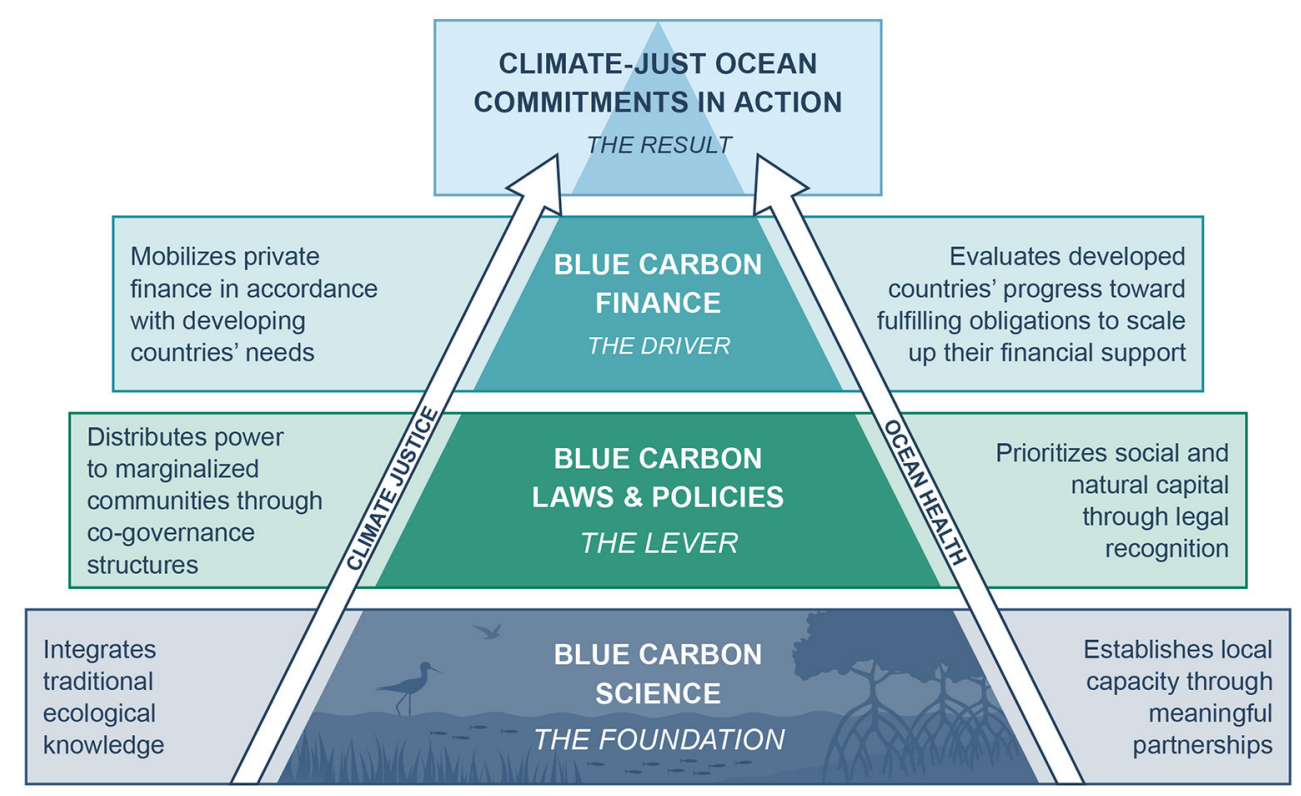

FIGURE 1 | A snapshot to guide the development of a framework for operationalizing climate-just ocean commitments under the Paris agreement.

carbon mapping and valuation, as suggested in Article 20 of the United Nations Declaration on the Rights of Indigenous Peoples (United Nations, 2007), Article 6 of the UNFCCC (United Nations Framework Convention on Climate Change, 1992), and Principle 22 in the Rio Declaration (United Nations, 1992). Moreover, the UNFCCC Subsidiary Body for Scientific and Technological Advance (SBSTA) in their Dialogue on the Ocean and Climate Change (United Nations Framework Convention on Climate Change Subsidiary Body for Scientific and Technological Advice, 2021) stated that resilience building should put people at the center: "ocean-related scientific knowledge, including traditional knowledge, provides the foundation for decisionmaking." Any blue carbon ecosystem management on or near indigenous land therefore has the opportunity and responsibility to engage, respect, and elevate local and indigenous knowledge and values (Vierros, 2017). An integrated approach that brings together the strengths of both TEK and western science has been shown to yield impactful results (Reid et al., 2021). In addition, TEK proves accurate in carrying out large-scale marine habitat surveys, while increasing community participation and acceptance of resulting regulations (Teixeira et al., 2013).

Participatory mapping and Geographic Information Systems (GIS) are methods seeking to involve local communities in coproduction or application of geographic data (Dunn, 2007). When these approaches are practiced successfully, they enable modern digital technologies to be combined with TEK, without privileging or invalidating any knowledge type (McCall and Minang, 2005; Dunn, 2007). While there are few studies that integrate TEK with blue carbon science, work by Brown et al. (2018) coupled the mapping of long-term changes in mangrove ecosystems with participatory mapping approaches, engaging Kabi Kabi Traditional Owners on the Maroochy River, Queensland, Australia, Demonstrating how western scientific approaches can complement TEK in the mapping of coastal habitats (Huntington, 2000; Drew, 2005; Mellado et al., 2014).

There is a clear gap in studies that include TEK in mapping and quantifying blue carbon habitats which must be filled in order for blue carbon to be mapped, quantified, and ultimately included in NDCs. Participatory GIS has proved successful in mapping carbon storage and other ecosystem services in terrestrial data-scarce areas (e.g., Paudyal et al., 2015), and thus, we recommend that this methodology be developed and replicated for mapping and quantifying carbon in coastal habitats. Moving forward, blue carbon science could consider coupling ecosystem service mapping and economic valuation with a range of participatory methodologies taking the form of semi-structured interviews (e.g., Roulston and Choi, 2018), mental modeling (e.g., Gray et al., 2012), focus group discussions (e.g., Phelan et al., 2020), oral history storytelling (e.g., Coutts and Urlich, 2020; Puniwai, 2020), transect walks (e.g., Paudyal et al., 2015), direct participatory mapping (e.g., Wahle and D'Iorio, 2010), digraph drawing (e.g., Moon et al., 2019), and more. This shift aligns with the UNFCCC's methodology notes for the REDD + scheme which stresses the role of local and traditional knowledge for measuring carbon stocks (United Nations Framework Convention on Climate Change Subsidiary Body for Scientific and Technological Advice, 2009; McCall, 2012).

\section{LAYER TWO: DRAFTING LAWS AND POLICIES CENTERED ON MARGINALIZED COMMUNITIES AND RIPE FOR INCLUSION OF BLUE CARBON STRATEGIES}

The inclusion of blue carbon sequestration in climate policies, from the local to international level, is emerging in tandem with the call for additional localized data on carbon sequestration 
TABLE 1 | National and subnational examples leading the way in operationalizing climate-just blue carbon strategies.

\begin{tabular}{|c|c|c|c|c|}
\hline & Guiding questions & Enabling conditions & Blue carbon tool & Example \\
\hline Science & $\begin{array}{l}\text { How many people had their } \\
\text { capacity built in the } \\
\text { process? Who are the } \\
\text { people who had their } \\
\text { capacity built? How long } \\
\text { does this capacity last? Will } \\
\text { opportunities be provided to } \\
\text { use it? Will value be given to } \\
\text { it (i.e., will they be paid to } \\
\text { monitor seagrass } \\
\text { meadows)? }\end{array}$ & $\begin{array}{l}\text { Include local scientists, } \\
\text { traditional ecological } \\
\text { knowledge, and } \\
\text { cultural value }\end{array}$ & $\begin{array}{l}\text { Locally } \\
\text { managed/created } \\
\text { marine protected areas } \\
\text { to ensure the } \\
\text { continuation of carbon } \\
\text { sequestration } \\
\text { ecosystem service }\end{array}$ & $\begin{array}{l}\text { Inclusion of tribal } \\
\text { considerations in the } \\
\text { design of a marine } \\
\text { protected area network } \\
\text { after lengthy } \\
\text { negotiations }\end{array}$ \\
\hline $\begin{array}{l}\text { Law and } \\
\text { policy }\end{array}$ & $\begin{array}{l}\text { How is management } \\
\text { structured in coastal } \\
\text { ecosystems predominantly } \\
\text { occurring on } \\
\text { public/government } \\
\text { property? How are } \\
\text { co-management structures } \\
\text { put in place? Who is } \\
\text { involved, what activities will } \\
\text { be done, and will it be } \\
\text { financed? }\end{array}$ & $\begin{array}{l}\text { Identify or draft laws } \\
\text { and policies ripe for the } \\
\text { uptake of blue carbon } \\
\text { strategies centred on } \\
\text { community needs and } \\
\text { designed with } \\
\text { co-governance } \\
\text { structures in mind. }\end{array}$ & $\begin{array}{l}\text { Coastal adaptation } \\
\text { policies that foster } \\
\text { integration of } \\
\text { nature-based solutions } \\
\text { that sequester carbon } \\
\text { emissions, such as } \\
\text { wetland restoration, } \\
\text { into climate-just local } \\
\text { coastal planning. }\end{array}$ & $\begin{array}{l}\text { Allocation of a } \\
\text { percentage of coastal } \\
\text { planning project funds } \\
\text { dedicated to } \\
\text { disadvantaged } \\
\text { communities as } \\
\text { defined under the law. }\end{array}$ \\
\hline Finance & $\begin{array}{l}\text { How are funds distributed } \\
\text { and to whom? To fund what } \\
\text { activities? How is impact } \\
\text { defined and monitored? } \\
\text { How are social/equity } \\
\text { indicators introduced? }\end{array}$ & $\begin{array}{l}\text { Mobilize private and } \\
\text { public finance that } \\
\text { preserves national } \\
\text { sovereignty, } \\
\text { incorporates social and } \\
\text { cultural values into } \\
\text { market valuations, and } \\
\text { has a positive or neutral } \\
\text { impact on developing } \\
\text { country debt burdens. }\end{array}$ & $\begin{array}{l}\text { Community based } \\
\text { marine spatial planning } \\
\text { undertaken in } \\
\text { exchange for sovereign } \\
\text { debt relief, that builds a } \\
\text { comprehensive } \\
\text { understanding of the } \\
\text { carbon sequestration } \\
\text { ecosystem service of } \\
\text { coastal ecosystems } \\
\text { such as seagrass. }\end{array}$ & $\begin{array}{l}\text { Negotiation of debt for } \\
\text { nature swaps, toward } \\
\text { sovereign } \\
\text { empowerment and } \\
\text { capacity building. }\end{array}$ \\
\hline
\end{tabular}

(Unsworth et al., 2018; Moritsch et al., 2021; Wedding et al., 2021). The utilization of existing laws and policies to address climate change challenges provide opportunities for advancement (Garmestani et al., 2019). For example, the role of a policy landscape ripe for inclusion of blue carbon strategies is at the forefront of subnational efforts to reduce carbon emissions pursuant to California's Global Warming Solutions Act of 2006 (Wedding et al., 2021). The under-utilization of existing environmental laws is implied to be the result of a lack of understanding by policymakers of how socio-ecological resilience can be integrated into current environmental governance frameworks (MacLean, 2020). Environmental regulations, laws, and policies are beginning to include coastal habitat protection for carbon sequestration as a mitigation strategy (Howard et al., 2017), with the co-benefit of adaptation (Duarte et al., 2013). Existing law and policy boundaries can be synthesized toward identifying areas that provide flexibility for the inclusion of blue carbon science into policy. For example, California has existing mechanisms for the uptake of blue carbon sequestration in its environmentally sensitive habitat and marine protected area structures, the incorporation of ecosystem services into local coastal planning decisions, and is considering a "Teal Deal" (i.e., state blue and green carbon strategy designed to use sequestered carbon in California climate plans and coastal conservation policy) (Dundas et al., 2020).

However, laws and policies could center further on the rights of the communities disproportionately more vulnerable to major disturbances (United Nations Department of Economic and Social Affairs, 2016) and less resilient to climate change impacts. Climate change mitigation measures can forcibly displace local communities, cut off or divert essential resources, and diminish developmental progress (Caetano et al., 2020). Moreover, policies supporting blue carbon implementation can further green gentrification, the pathway by which green amenities lead to displacement (Anguelovski et al., 2018; Arnold, 2021).

New and existing laws and policies poised for the uptake of blue carbon strategies require further examination to ensure they center on marginalized communities and embody a design which builds social capital, empowers residents, and addresses community-defined needs. For example, these needs are being identified through coastal adaptation policies in California, where legislation requires that a quarter of funding derived from the cap-and-trade program and deposited in the Greenhouse Gas Reduction Fund goes to projects in disadvantaged communities 
(California AB1550, California Health Safety Code, 2016). The California Environmental Protection Agency is responsible for identifying disadvantaged communities (California SB 535, California Health Safety Code, 2012) assessed through geographic, socioeconomic, public health, and environmental hazard criteria [California Health Safety Code, 2014, Section 39711(a)-(b)]. As a result of California's emerging climate policy framework, coastal climate adaptation grant proposals must benefit disadvantaged communities living within, or reliant upon coastal zones (California Coastal Commission, 2019). The conditions placed on grant proposals acknowledge that many disadvantaged communities cannot afford to live within the coastal zone, but may rely upon it for access to livelihood and recreation. While California's cap-and-trade program has been subject to both scientific and legal critique, it demonstrates the role of law and policy levers in driving change toward acknowledging both blue carbon science, and the inclusion of disadvantaged communities.

\section{LAYER THREE: STRUCTURING FINANCIAL MECHANISMS TO PRESERVE NATIONAL SOVEREIGNTY AND SUPPORT BLUE CARBON PROJECTS}

Developing countries' NDC mitigation and adaptation targets are often conditioned on obtaining financing: of the 168 NDCs submitted as of September 2018, 136 were conditioned on receiving support in the form of capacity building, mitigation finance, technology transfer, and adaptation finance (Pauw et al., 2020). While the Paris Agreement requires developed countries to provide financial resources to developing countries for mitigation and adaptation, it does not specify the type or source of financing that must be provided (United Nations, 2015). To date, public financing has fallen well short of the amount needed to meet the goals of the Paris Agreement (IPCC, 2018; Choi and Seiger, 2020). As a result, both developed and developing countries are turning to the private sector to fill the gap. To meet the Paris Agreement's human rights aspirations, public and private sector climate-just financing should acknowledge the legacy of colonialism-characterized by resource extraction, exploitation of local labor, and devaluation of local cultures and indigenous knowledge, followed by high levels of debt owed to former colonizers (Chase, 2019; Dix, 2021) - and responsibility for historic GHG emissions.

Blue bonds-commercial debt instruments whose proceeds are used to finance water, marine, and ocean-based projects yielding positive environmental, economic, and climate benefits [Blue Natural Capital Financing Facility (BNCFF), 2019]and blended finance-which leverages concessional loans and grants from public and philanthropic sources to attract private sector investors seeking market-rate returns (Choi and Seiger, 2020) - are two financing mechanisms that have quickly gained traction in the private investment community (Choi and Seiger, 2020; Giorgi and Michetti, 2021). While these private sector innovations mobilize mitigation and adaptation funding, this funding may come at a social cost by adding to developing countries' national debt, which constrains their ability to invest in vital infrastructure and social services and to grow their economies sustainably. This consequence of national debt repayment can lead to higher taxes and increased exports of raw materials and agricultural products which damage the environment and local and indigenous communities [Silny, 2011; Lamman and MacIntyre, 2016; Caritas International International Cooperation for Development and Solidarity (CIDSE), 2021].

Carbon markets can provide income to developing countries and local and indigenous communities, and are opening up to blue carbon projects. Methodologies for blue carbon conservation and restoration have been approved by several carbon credit standards (e.g., Verra., 2015), and blue carbon is now part of UNREDD+ (He et al., 2016). However, carbon markets raise several climate justice issues. The current price of carbon is far below the amount needed to fairly compensate developing countries for relinquishing profitable development opportunities in order to conserve ecosystems that sequester carbon. Carbon markets can have adverse impacts on indigenous communities by providing land-and carbongrabbing opportunities to foreign investors or state governments (Fairhead et al., 2012; Rights Resources Initiative, 2014). Also, while some indigenous communities participate in carbon markets, including those in northern Australia that use funding from the Australian government's Emissions Reduction Fund to support savannah burning projects (Sangha et al., 2018), many indigenous cultures-particularly those that view the sea as "mother"-are opposed to the commodification and sale of coastal ecosystem services (Kenner, 2014; Damanik, 2015). Assigning simple financial valuation without incorporating local socio-cultural or spiritual values associated with coastal ecosystems can perpetuate colonial relations (Goodman and Roberts, 2010), disrespecting indigenous and traditional cultures, beliefs, and well-being (Kenner, 2014).

Debt-for-nature swaps provide sovereign debt restructure on more favorable terms in exchange for commitments to invest in conservation and sustainability projects (The Commonwealth, 2018). A common perception is that these swaps place restrictions on what developing countries can do with their own resources. However, the details of the swaps can be negotiated and implemented to preserve national sovereignty for the developing nation while meeting financial and environmental conditions of creditors. For example, in structuring their 2018 debt-for-nature swap, the Seychelles negotiated funding for a comprehensive marine spatial plan, resulting in the most consultative process in the design of the plan as well as capacity building of Seychellois in marine spatial planning.

In addition to mobilizing climate-just private financing, developed countries must be held accountable for meeting their obligation to scale up public financing for developing countries' mitigation and adaptation efforts under the Paris Agreement. Unfortunately, accountability and transparency in meeting climate finance pledges have been difficult to manage and enforce, especially since no agreed methodology or tracking mechanism for climate financing is provided under the UNFCCC (Haites, 2013). Participants at the aforementioned SBSTA 
Dialogue on the Ocean and Climate Change recommended the development of a practical guide to Ocean and climate financing, alongside technical guidelines and criteria to aid the Green Climate Fund and Global Environment Facility drive investment in Ocean nature-based solutions (United Nations Framework Convention on Climate Change Subsidiary Body for Scientific and Technological Advice, 2021).

\section{CONCLUSION}

The disproportionate impacts of climate change should be addressed in a manner that acknowledges a legacy of colonialism and inequality. To move climate justice from preamble to practice, we propose the development of a framework to operationalize Ocean commitments made by Parties. In this framework, blue carbon science values local and traditional knowledge, law and policy centers on marginalized communities, and financial mechanisms respect national sovereignty and promote sustainable economic development. Each layer works together to bridge the gap between the spirit and practicality of the Paris Agreement and implementation of climatejust solutions.

Building on the momentum generated by COP25 and the commencement of the Decade of Ocean Science, the Oceanclimate nexus will be center stage at COP26. Inclusion of a framework in Ocean-climate nexus discussions and decisionmaking would assist Parties as they prepare to execute the Ocean commitments contained in their NDCs in a climate-just manner. In addition, to promote large-scale operationalization of Ocean-inclusive NDCs, Parties could consider a framework in the Global Stocktake as a way to assess progress and inform future action on climate-just Ocean nature-based solutions in

\section{REFERENCES}

Anguelovski, I., Connolly, J. J., Masip, L., and Pearsall, H. (2018). Assessing green gentrification in historically disenfranchised neighborhoods: a longitudinal and spatial analysis of Barcelona. Urban Geogr. 39, 458-491. doi: 10.1080/02723638.2017.134 9987

Arnold, C. A. (2021). "Resilience justice and community-based green and blue infrastructure," in William \& Mary Environmental Law and Policy Review, Vol. 45. University of Louisville School of Law Legal Studies Research Paper Series No. 2021-3, 665-737. Available online at: https://ssrn.com/abstract=3799314

Beaumont, N. J., Jones, L., Garbutt, A., Hansom, J. D., and Toberman, M. (2014). The value of carbon sequestration and storage in coastal habitats. Estuar. Coast. Shelf Sci. 137, 32-40. doi: 10.1016/j.ecss.2013. 11.022

Bindoff, N., Cheung, W., Kairo, J., Aristegui, J., Guinder, V., Hallberg, R., et al. (2019). "Changing ocean, marine ecosystems, and dependent communities," in Special Report on Ocean and Cryosphere in a Changing Climate, eds H. O. Portner, D. Roberts, V. Masson-Delmotte, and P. Zhai (Geneva: Intergovernmental Panel on Climate Change), 447-587.

Blue Natural Capital Financing Facility (BNCFF) (2019). Blue Bonds: Financing Resilience of Coastal Ecosystems: Key Points for Enhancing Finance Action.

Brown, M. I., Pearce, T., Leon, J., Sidle, R., and Wilson, R. (2018). Using remote sensing and traditional ecological knowledge (TEK) to understand mangrove change on the Maroochy River, Queensland, Australia. Appl. Geogr. 94, 71-83. doi: 10.1016/j.apgeog.2018.03.006 climate mitigation and adaptation (United Nations Framework Convention on Climate Change Subsidiary Body for Scientific and Technological Advice, 2021).

\section{DATA AVAILABILITY STATEMENT}

The original contributions presented in the study are included in the article/supplementary material, further inquiries can be directed to the corresponding author.

\section{AUTHOR CONTRIBUTIONS}

All authors contributed to manuscript development, revision, read, and approved the submitted version.

\section{FUNDING}

A Vermont Law School Travel and Research Stipend supported the publication fees. University of Oxford, ESRC IAA Knowledge Exchange Dialogues Award.

\section{ACKNOWLEDGMENTS}

The authors wish to thank the Vermont Law School student delegates who supported the Seychelles Conservation and Climate Adaptation Trust in advance of COP26, and Dr. Chloë Montes Strevens and the University of Oxford Biodiversity, Conservation, and Management MSc/MPhil students who participated in a workshop on assessing ambition and conditionality in Nationally Determined Contributions under the Paris Agreement.

Caetano, T., Winker, H., and Depledge, J. (2020). Towards zero carbon and zero poverty: integrating national climate change mitigation and sustainable development goals. Climate Policy 20, 773-778. doi: 10.1080/14693062.2020.17 91404

California Coastal Commission (2019). Recommended Round 6 Local Coastal Program Local Assistance Grant Awards. San Francisco, CA: California Coastal Commission.

California Health and Safety Code (2016). AB-1550 Greenhouse Gases: Investment Plan: Disadvantaged Communities.

California Health and Safety Code (2012). SB-535, De León. California Global Warming Solutions Act of 2006: Greenhouse Gas Reduction Fund.

California Health and Safety Code (2014). "Division 26, State Air Resources Board, in Chapter 4.1. Greenhouse Gas Reduction Fund Investment Plan and Communities Revitalisation Act [39710-39723].

Caritas International and International Cooperation for Development and Solidarity (CIDSE) (2021). How Did the Debt Crisis Come About? What Was Its Impact on Poor Countries? Available online at https://www.worldhunger.org/ articles/global/debt/caritas2.html (accessed July 15, 2021).

Chase, N. (2019). Barbados' Debt Crisis: The Effects of Colonialism and Neoliberalism. Latin American, Caribbean, and U.S. Latino Studies Honors Program 4. State University of New York.

Choi, E., and Seiger, A. (2020). Catalyzing Capital for the Transition Toward Decarbonization: Blended Finance and Its Way Forward. Stanford Sustainable Finance Initiative. Available online at: https://energy.stanford.edu/sites/g/ files/sbiybj9971/f/sfi_blended_finance_and_its_way_forward_spring_2020.pdf (accessed March 24, 2021). doi: 10.2139/ssrn.3627858 
Coutts, G. L., and Urlich, S. (2020). A Local Oral History of Environmental Change in Pelorus/Te Hoiere. Lincoln University.

Crooks, S., Herr, D., Tamelander, J., Laffoley, D., and Vandever, J. (2011). Mitigating Climate Change Through Restoration And Management of Coastal Wetlands and Near-Shore Marine Ecosystems: Challenges and Opportunities, Washington, DC: World Bank.

Damanik, R. (2015). Fisherfolks are Pushing the Solution, Not the Illusion of Blue Carbon. Transnational Institute.

Dix, K. (2021). Blue Neocolonialism. Uneven Earth. Available online at: http:// unevenearth.org/2021/01/blue-neocolonialism (accessed April 10, 2021).

Drew, J. A. (2005). Use of traditional ecological knowledge in marine conservation. Conserv. Biol. 19, 1286-1293. doi: 10.1111/j.1523-1739.2005.00158.x

Duarte, C. M., Losada, I. J., Hendriks, I. E., Mazarrasa, I., and Marbà, N. (2013). The role of coastal plant communities for climate change mitigation and adaptation. Nat. Clim. Change 3, 961-968. doi: 10.1038/nclimate1970

Dundas, S. J., Levine, A. S., Lewison, R. L., Doerr, A. N., White, C., Galloway, A. W., et al. (2020). Integrating oceans into climate policy: any green new deal needs a splash of blue. Conserv. Lett. 13:e12716. doi: 10.1111/conl.12716

Dunn, C. E. (2007). Participatory GIS-a people’s GIS? Prog. Human Geogr. 31, 616-663. doi: 10.1177/0309132507081493

Fairhead, J., Leach, M., and Scoones, I. (2012). Green grabbing: a new appropriation of nature? J. Peasant Stud. 39, 237-261. doi: $10.1080 / 03066150.2012 .671770$

Gallo, N. D., Victor, D. G., and Levin, L. A. (2017). Ocean commitments under the Paris agreement. Nat. Clim. Change 7, 833-838. doi: 10.1038/nclimate3422

Garmestani, A., Ruhl, J. B., Chaffin, B. C., Craig, R. K., van Rijswick, H. F., Angeler, D. G., et al. (2019). Untapped capacity for resilience in environmental law. Proc. Natl. Acad. Sci. U.S.A. 116, 19899-19904. doi: 10.1073/pnas.1906247116

Giorgi, A., and Michetti, C. (2021). Climate Investment Opportunities: ClimateAligned Bonds and Issuers. Ho Chi Minh: Climate Bonds Initiative.

Goodman, J., and Roberts, E. (2010). Is the United Nations REDD scheme conservation colonialism by default? Int. J. Water 5, 419-428. doi: 10.1504/IJW.2010.038733

Gray, S., Chan, A., Clark, D., and Jordan, R. (2012). Modeling the integration of stakeholder knowledge in social-ecological decision-making: benefits and limitations to knowledge diversity. Ecol. Modell. 229, 88-96. doi: 10.1016/j.ecolmodel.2011.09.011

Green, A. E., Unsworth, R. K., Chadwick, M. A., and Jones, P. J. (2021). Historical analysis exposes catastrophic seagrass loss for the United Kingdom. Front. Plant Sci. 12:261. doi: $10.3389 /$ fpls.2021.629962

Haites, E. (2013). International Climate Finance. Oxfordshire: Routledge.

He, X., Hernandez, C., Lamb, E., Sepulveda, T. G., and Schwaner, C. (2016). Creating a Toolkit for Implementing Blue Carbon Projects! Duke University.

Himes-Cornell, A., Pendleton, L., and Atiyah, P. (2018). Valuing ecosystem services from blue forests: a systematic review of the valuation of salt marshes, seagrass beds and mangrove forests. Ecosyst. Serv. 30, 36-48. doi: 10.1016/j.ecoser.2018.01.006

Howard, J., McLeod, E., Thomas, S., Eastwood, E., Fox, M., Wenzel, L., et al. (2017). The potential to integrate blue carbon into MPA design and management. Aquat. Conserv.: Mar. Freshw. Ecosyst. 27, 100-115. doi: 10.1002/aqc.2809

Hunsberger, C., Corbera, E., Borras, S. M. Jr, Franco, J. C., Woods, K., Work, C., et al. (2017). Climate change mitigation, land grabbing and conflict: towards a landscape-based and collaborative action research agenda. Can. J. Dev. Stud. 38, 305-324. doi: 10.1080/02255189.2016.1250617

Huntington, H. P. (2000). Using traditional ecological knowledge in science: methods and applications. Ecol. Appl. 10, 1270-1274. doi: 10.1890/1051-0761(2000)0101270:UTEKIS2.0.CO;2

IPCC (2018). Global Warming of $1.5^{\circ} \mathrm{C}$. An IPCC Special Report on the Impacts of Global Warming of $1.5^{\circ} \mathrm{C}$ Above Pre-Industrial Levels and Related Global Greenhouse Gas Emission Pathways, in the Context of Strengthening the Global Response to the Threat of Climate Change, Sustainable Development, and Efforts to Eradicate Poverty. IPCC.

IPCC (2013). Supplement to the 2006 IPCC Guidelines for National Greenhouse Gas Inventories: Wetlands. Geneva: IPCC.

Kenner, D. (2014). Who Should Value Nature? Why Green Economy? Institute of Chartered Accountants in England and Wales.

Lamman, C., and MacIntyre, H. (2016). Growing Government Debt Could Endanger Future Prosperity in Canada. Fraser Institute.
Lecerf, M., Herr, D., Thomas, T., Elverum, C., Delrieu, E., and Picourt, L. (2021). Coastal and Marine Ecosystems as Nature-Based Solutions in New or Updated Nationally Determined Contributions. Arlington: The Nature Conservancy.

MacLean, J. (2020). Learning to overcome political opposition to transformative environmental law. Proc. Natl. Acad. Sci. U.S.A. 117, 8243-8244. doi: 10.1073/pnas.1921436117

McCall, M. K. (2012). "Local participation in mapping, measuring and monitoring for community carbon forestry," in Community Forest Monitoring for the Carbon Market (Oxfordshire: Routledge), 51-64.

McCall, M. K., and Minang, P. A. (2005). Assessing participatory GIS for community-based natural resource management: claiming community forests in Cameroon. Geogr. J. 171, 340-356. doi: 10.1111/j.1475-4959.2005.00173.x

Mcleod, E., Chmura, G. L., Bouillon, S., Salm, R., Björk, M., Duarte, C. M., et al. (2011). A blueprint for blue carbon: toward an improved understanding of the role of vegetated coastal habitats in sequestering CO2. Front. Ecol. Environ. 9, 552-560. doi: 10.1890/110004

Mellado, T., Brochier, T., Timor, J., and Vitancurt, J. (2014). Use of local knowledge in marine protected area management. Mar. Policy 44, 390-396. doi: 10.1016/j.marpol.2013.10.004

Moon, K., Guerrero, A. M., Adams, V. M., Biggs, D., Blackman, D. A., Craven, L., et al. (2019). Mental models for conservation research and practice. Conserv. Lett. 12:e1264. doi: 10.1111/conl.12642

Moritsch, M. M., Young, M., Carnell, P., Macreadie, P. I., Lovelock, C., Nicholson, E., et al. (2021). Estimating blue carbon sequestration under coastal management scenarios. Sci. Total Environ. 777:145962. doi: 10.1016/j.scitotenv.2021.145962

Paudyal, K., Baral, H., Burkhard, B., Bhandari, S. P., and Keenan, R. J. (2015). Participatory assessment and mapping of ecosystem services in a data-poor region: case study of community-managed forests in central Nepal. Ecosyst. Serv. 13, 81-92. doi: 10.1016/j.ecoser.2015.01.007

Pauw, W. P., Castro, P., Pickering, J., and Bhasin, S. (2020). Conditional nationally determined contributions in the Paris agreement: foothold for equity or Achilles heel? Climate Policy 20, 468-484. doi: 10.1080/14693062.2019.1635874

Penz, P., Drydyk, J., and Bose, P. S. (2011). Displacement by Development: Ethics, Rights and Responsibilities. Cambridge: Cambridge University Press. doi: 10.1017/CBO9780511973499

Phelan, A., Ross, H., Setianto, N. A., Fielding, K., and Pradipta, L. (2020). Ocean plastic crisis-Mental models of plastic pollution from remote Indonesian coastal communities. PLoS ONE 15:e0236149. doi: 10.1371/journal.pone.0236149

Puniwai, N. (2020). Pua ka wiliwili, nanahu ka mano: understanding sharks in Hawaiian culture. Human Biol. 92:11. doi: 10.13110/humanbiology.92.1.03

Reid, A. J., Eckert, L. E., Lane, J. F., Young, N., Hinch, S. G., Darimont, C. T., et al. (2021). "Two-eyed seeing": an indigenous framework to transform fisheries research and management. Fish Fish. 22, 243-261. doi: 10.1111/faf. 12516

Rights and Resources Initiative (2014). Status of Forest Carbon Rights and Implications for Communities, The Carbon Trade, and REDD + Investments. Rights and Resources Institute.

Robinson, M., and Shine, T. (2018). Achieving a climate justice pathway to $1.5^{\circ} \mathrm{C}$. Nat. Clim. Change 8, 564-569. doi: 10.1038/s41558-018-0189-7

Roulston, K., and Choi, M. (2018). Qualitative Interviews. The SAGE Handbook of Qualitative Data Collection. Newcastle upon Tyne: SAGE. doi: 10.4135/9781526416070.n15

Sangha, K. K., Preece, L., Villarreal-Rosas, J., Kegamba, J. J., Paudyal, K., Warmenhoven, T., et al. (2018). An ecosystem services framework to evaluate indigenous and local peoples' connections with nature. Ecosyst. Serv. 31, 111-125. doi: 10.1016/j.ecoser.2018.03.017

Seddon, N., Sengupta, S., García-Espinosa, M., Hauler, I., Herr, D., and Rizvi, A. R. (2019). Nature-based Solutions in Nationally Determined Contributions. Gland: ICUN and the University of Oxford.

Silny, J. (2011). Debt as an Obstacle to Development. Ecumenical Academy Prague.

Teixeira, J. B., Martins, A. S., Pinheiro, H. T., Secchin, N. A., de Moura, R. L., and Bastos, A. C. (2013). Traditional ecological knowledge and the mapping of benthic marine habitats. J. Environ. Manag. 115, 241-250. doi: 10.1016/j.jenvman.2012.11.020

The Commonwealth (2018). Case Study: Debt-for-Nature Finance Swap. Commonwealth Small States Center of Excellence. Available online at: 
https://seyccat.org/wp-content/uploads/2019/07/SSCOE-Debt-for-NatureSeychelles-Case-Study-final.pdf (accessed March 5, 2021).

Thornton, P. E., Doney, S. C., Lindsay, K., Moore, J. K., Mahowald, N., Randerson, J. T., et al. (2009). Carbon-nitrogen interactions regulate climate-carbon cycle feedbacks: results from an atmosphere-ocean general circulation model. Biogeosciences 6, 2099-2120. doi: 10.5194/bg-6-209 9-2009

United Nations (1992). Report of the United Nations Conference on Environment and Development. United Nations Publication.

United Nations (2007). "United Nations declaration on the rights of indigenous peoples," in Proceedings of the General Assembly 2007. New York, NY: General Assembly.

United Nations (2015). "Paris agreement," in Proceedings of the Report of the Conference of the Parties to the United Nations Framework Convention on Climate Change (Paris).

United Nations Department of Economic and Social Affairs (2016). "Climate change resilience: an opportunity for reducing inequalities," in Proceedings of the World Economic and Social Survey, 2016 (New York, NY).

United Nations Framework Convention on Climate Change (1992). Proceedings of the General Assembly (New York, NY).

United Nations Framework Convention on Climate Change (2018). "Matters relating to Article 14 of the Paris," in Proceedings of the Report of the Conference of the Parties Serving as the Meeting of the Parties to the Paris Agreement (Katowice).

United Nations Framework Convention on Climate Change Subsidiary Body for Scientific and Technological Advice (2009). "Reducing emissions from deforestation in developing countries: approaches to stimulate action," in Proceedings of the Issues Relating to Indigenous People and Local Communities for the Development and Application of Methodologies (Bonn).

United Nations Framework Convention on Climate Change Subsidiary Body for Scientific and Technological Advice (2021). Ocean and Climate Change Dialogue to Consider How to Strengthen Adaptation and Mitigation Action. Informal Summary Report by the Chair of the Subsidiary Body for Scientific and Technological Advice. United Nations Framework Convention on Climate Change.

Unsworth, R. K., Ambo-Rappe, R., Jones, B. L., La Nafie, Y. A., Irawan, A., Hernawan, U. E., et al. (2018). Indonesia's globally significant seagrass meadows are under widespread threat. Sci. Total Environ. 634, 279-286. doi: 10.1016/j.scitotenv.2018.03.315

Verra. (2015). VM0033 Methodology for Tidal Wetland and Seagrass Restoration, v1. 0. Washington, DC: Verified Carbon Standard.

Vierros, M. (2017). Communities and blue carbon: the role of traditional management systems in providing benefits for carbon storage, biodiversity conservation and livelihoods. Clim. Change 140, 89-100. doi: 10.1007/s10584-013-0920-3

Wahle, C. M., and D'Iorio, M. M. (2010). Mapping human uses of the ocean informing marine spatial planning through participatory GIS.

Wedding, L. M., Moritsch, M., Verutes, G., Arkema, K., Hartge, E., Reiblich, J., et al. (2021). Incorporating blue carbon sequestration benefits into sub-national climate policies. Glob. Environ. Change 69:102206. doi: $10.1016 /$ j.gloenvcha.2020.102206

Conflict of Interest: AP often serves as a member of the Seychelles party delegation to the UNFCCC climate negotiations. SMR is the Head of the Vermont Law School Observer Delegation to the UNFCCC climate negotiations.

The remaining co-authors are not directly involved with the NGO movement for climate-just ocean commitments and declare that the research was conducted in the absence of any commercial or financial relationships that could be construed as a potential conflict of interest.

Publisher's Note: All claims expressed in this article are solely those of the authors and do not necessarily represent those of their affiliated organizations, or those of the publisher, the editors and the reviewers. Any product that may be evaluated in this article, or claim that may be made by its manufacturer, is not guaranteed or endorsed by the publisher.

Copyright $\odot 2021$ Reiter, Cheng, Pouponneau, Taylor and Wedding. This is an open-access article distributed under the terms of the Creative Commons Attribution License (CC BY). The use, distribution or reproduction in other forums is permitted, provided the original author(s) and the copyright owner(s) are credited and that the original publication in this journal is cited, in accordance with accepted academic practice. No use, distribution or reproduction is permitted which does not comply with these terms. 